\title{
2.4 Бухгалтерський облік в системі управління підприємством
}

Українські підприємства в сучасних умовах господарювання потребують чітко визначеної гнучкої системи заходів, спрямованих на забезпечення та вдосконалення управління господарською діяльністю. Економічні, фінансові та інші показники виробничо-фінансової діяльності, які застосовуються в обліковоаналітичній практиці, так як і методи їх оцінки та використання в системі управління підприємством, мають суттєві недоліки. В даних умовах найбільш важливим елементом управління господарською діяльністю виступає бухгалтерський облік, раціональна організація якого $\epsilon$ передумовою ефективного управління підприємством.

Проблеми організації i методики бухгалтерського обліку постійно знаходяться в центрі уваги науковців і економістів усіх країн світу. Велика кількість вчених внеслии вагомий внесок у розвиток бухгалтерського обліку в управлінні суб'єктом господарювання. Однак, питанням ефективного використання бухгалтерського обліку, саме для прийняття управлінських рішень, не приділяється належної уваги.

Бухгалтерський облік як складова системи управління $\epsilon$ впорядкованою системою збору, накопичення, реєстрації, класифікації, й узагальнення інформації у грошовому вимірнику про майно, капітал і зобов'язання підприємства та їх рух шляхом суцільного, безперервного й документального відображення всіх господарських операцій.

Бухгалтерський облік є складною системою - сукупністю елементів, пов'язаних між собою та об'єднаних в єдине ціле. Виступаючи ланкою зв'язку між господарською діяльністю та особами, які приймають рішення, бухгалтерський облік:

- вимірює господарську діяльність шляхом реєстрації даних про неї для подальшого використання;

- обробляє дані та інтерпретує їх таким чином, щоб вони набули практичної корисності; 
- передає у вигляді звітів інформацію тим, хто використовує ії для прийняття управлінських рішень.

Таким чином, дані про господарську діяльність є входом до системи бухгалтерського обліку, а інформація для осіб, що приймають рішення, виходом з неї [32].

Для прийняття управлінських рішень користувачам необхідно, щоб вони мали достовірну та об’єктивну інформацію про майно, фінансове становище, результати роботи, а також про процеси їх формування на підприємстві. Таку інформацію надає саме бухгалтерська система обліку [31]. Бухгалтерський облік - це частина інформаційного забезпечення підприємства (рис.1).

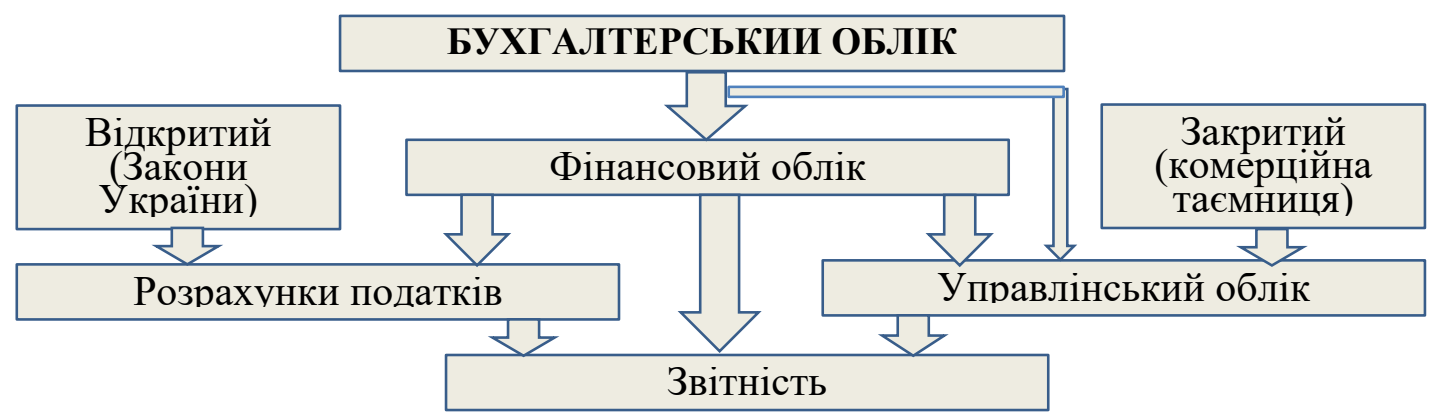

Рис. 1. Структура бухгалтерського обліку

Кожен рівень організації бухгалтерської інформації відповідає за різні функції:

- первинний облік включає збір, реєстрацію й обробку інформації;

- фінансовий облік відповідає за формування бухгалтерських проводок, бухгалтерських регістрів, бухгалтерської фінансової звітності з використанням методів бухгалтерського обліку;

- управлінський облік відповідає за одержання підсумкової достовірної інформації в будь-яких вимірниках для прийняття управлінських рішень, планування та аналізу фінансово-господарської діяльності підприємства;

- податковий облік відповідає за формування податкових регістрів, отримання інформації для цілей податкового планування;

- екологічний облік сприяє формуванню інформації про екологічну відповідальність підприємства;

- соціальний облік відповідає за формування показників соціального 
забезпечення працівників та власників підприємства;

- бюджетування дозволяє встановити планові показники, необхідні для реалізації стратегії забезпечення економічної безпеки підприємства;

- внутрішній аудит сприяє оцінці правильності ведення різних видів обліку на підприємстві з метою забезпечення його безпеки.

У вузькому розумінні управління - це перетворення інформації про стан об'єкта в командну інформацію від суб'єкта. У широкому розумінні цілеспрямований програмований чи довільний вплив на об'єкти задля досягнення кінцевої мети за допомогою процесорів, явищ, процесів, коли є 3 ними взаємодія в режимі детермінованої чи довільної програми (регламенту). В будь-якому випадку в процесі управління (прийняття управлінських рішень) взаємодіють об'єкти та суб'єкти, що дає можливість розглядати процес управління підприємством як систему управління, доповнену інструментами регулювання, інформаційною та результативною складовими тощо [34].

Таким чином, система управління підприємством - це спосіб взаємодії між управлінським персоналом та виконавцями щодо досягнення поставлених цілей фінансово-господарської діяльності підприємства.

Система бухгалтерського обліку - це своєрідний механізм підготовки та відображення інформації про майнове та фінансове становище підприємства. Завдяки цій інформації внутрішні та зовнішні ії користувачі мають уявлення про реальний стан справ на підприємстві. Система бухгалтерського обліку $є$ частиною інформаційної системи підприємства, оскільки вона будується на єдиній методологічній основі, що дозволяє адекватно відобразити діяльність підприємства, сформувати достовірні дані про майновий і фінансовий стан на рівні суб'єктів господарювання, здійснювати аналіз фінансово-господарської діяльності для прийняття управлінських рішень та постійний контроль за його показниками. Аналіз системи бухгалтерського обліку, зпредставлено на рис. 2. 


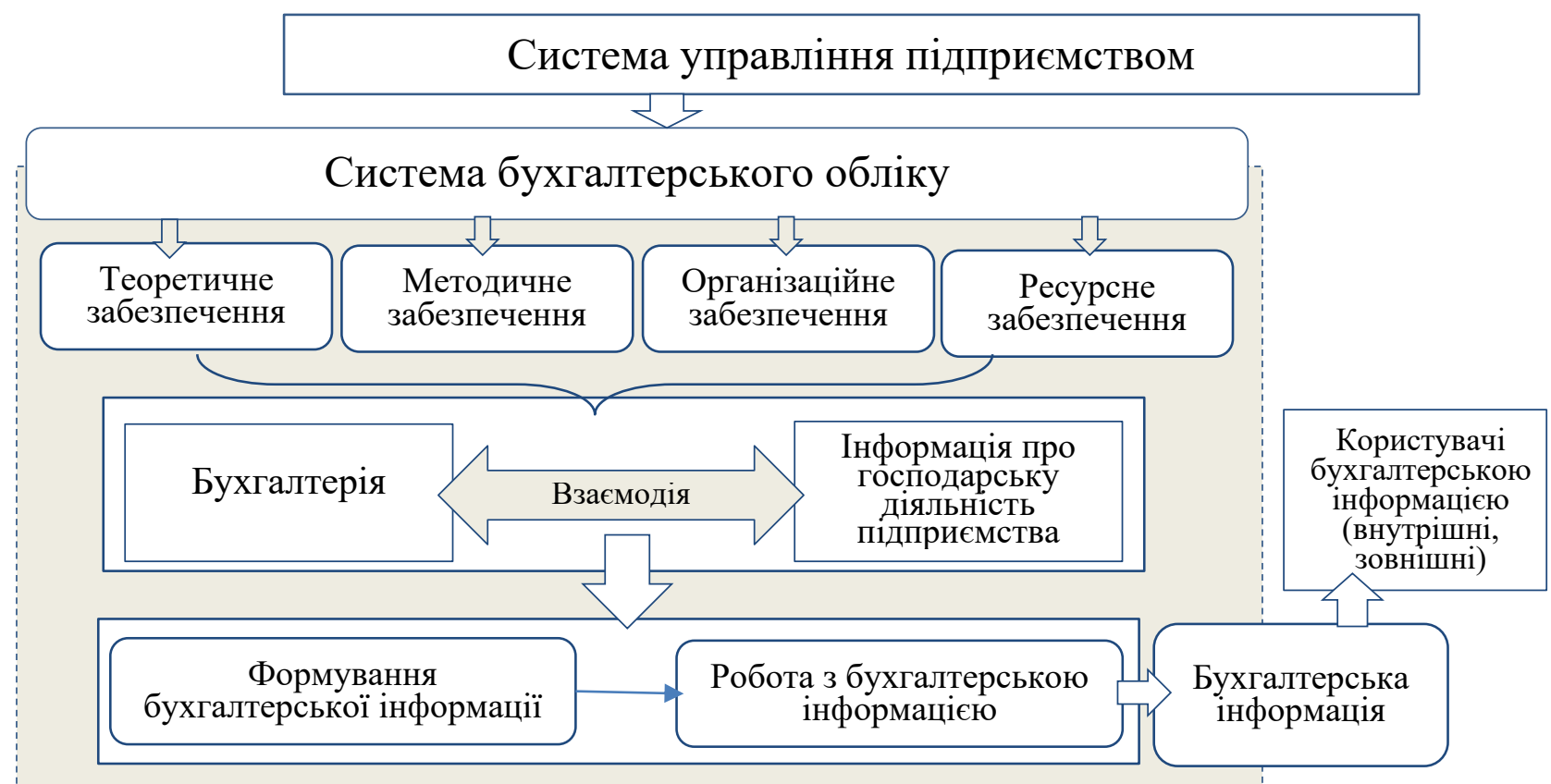

Рис. 2. Система бухгалтерського обліку в загальній системі управління підприємством

Система бухгалтерського обліку повинна формувати інформацію, що задовольняє потребам широкого кола зацікавлених користувачів. Сучасний бухгалтерський облік $є$ інформаційною базою, на основі якої можлива підготовка різних видів бухгалтерської і іншої звітності, зокрема, фінансової звітності, консолідованої фінансової звітності, управлінської звітності, податкової звітності, статистичної звітності, звітності перед державними органами контролю тощо.

Реалізація кінцевої мети функціонування підприємства забезпечується ефективною взаємодією керуючої та керованої складових системи управління ним, що забезпечується через виконання нею основоположних функцій управління: планування, організація, мотивація, контроль. На виконання вказаних функцій у досягненні цілей управління має вагомий вплив система бухгалтерського обліку [33].

Вплив зовнішнього та внутрішнього соціально-економічного середовища на господарську діяльність підприємства продукує виникнення низки фактів господарського життя, пов'язаних із процесами постачання, виробництва та реалізації. Багатогранність даних процесів зумовлена необхідністю залучення до господарського обороту фінансових, матеріальних, трудових, інформаційних та інших ресурсів, визначення предмету діяльності, вибору способів виробництва, 
формування цінової та збутової політики тощо.

Факти господарського життя, що призводять до зміни у структурі господарських засобів та джерелах їх утворення, ідентифікуються в систему бухгалтерського обліку як господарські операції, в якій вони реєструються, систематизуються, групуються та узагальнюються. Таким чином, формується масив обліково-економічної інформації, яка використовується керованою системою як інформаційне джерело при прийнятті управлінських рішень.

В цілому, економічна інформаційна система представлена підсистемами (планування, обліку, аналізу та контролю), що обумовлено можливістю виділити сукупність взаємопов'язаних елементів, які виконують відносно незалежні функції, але спрямовані на досягнення загальних цілей першої. Система через підсистеми покликана забезпечувати своєчасною, прогнозною, достовірною, доступною, доречною, комплексною та порівняною інформацію.

Бухгалтерський облік як функція управління, активно взаємодіє з іншими функціями, такими як: планування, контроль та аналіз. Елементи методу бухгалтерського обліку (документування, інвентаризація, рахунки, подвійний запис, оцінка, калькулювання, баланс та звітність) слід розглядати в якості інструментів підготовки релевантних даних на всіх етапах прийняття управлінських рішень.

Найбільш важливими для бухгалтерського управлінського обліку $є$ операції управління витратами, доходами та результатами через вплив як на витрати, так і на доходи. Причому управління результатами здійснюється через використання фінансових індикаторів (інформація, яка отримана в системі бухгалтерського обліку). Однак орієнтація на оцінку лише результативності діяльності підприємства (співвідношення доходів і витрат) є недостатньою, оскільки не дає можливості оцінити вплив на вартість нематеріальних активів (знань та досвіду ключових співробітників; відносин із клієнтами і партнерами; використання передових технологій тощо, які в сучасних умовах є основним джерелом конкурентоспроможності підприємств).

Внаслідок накопичення невідповідностей, управлінський облік, який 
грунтується на бухгалтерському обліку, може у кінцевому підсумку показати фінансовий результат, далекий від реальності, у той час як власники та потенційні інвестори прагнуть отримувати інформацію про реальний стан справ на підприємстві з метою порівняння альтернативних варіантів капіталовкладень. Лише фінансові показники не дають повної та адекватної картини розвитку підприємства та висвітлюють стан підприємства, що склався на момент оцінки, коли реагувати вже пізно.

Управлінський облік i контроль здійснюються на основі даних бухгалтерського обліку (бухгалтерський баланс, звіт про прибутки та збитки, звіт про рух грошових коштів організації). Недоліками базування управлінського обліку на даних бухгалтерського обліку та винятково на фінансових показниках $\epsilon$ такі:

1) бухгалтерський облік ведеться згідно із законодавчо встановленими вимогами, внаслідок чого не завжди відображає реальний стан справ підприємства (зокрема: вимоги щодо методів партійного обліку; методів нарахування амортизації; методів розподілу накладних витрат тощо);

2) дані про прибуток, отримані зі звіту про прибутки та збитки, не $є$ адекватними вимірниками прибутку, оскільки прибуток у системі бухгалтерського обліку залежить від того, коли були визнані доходи чи витрати. Більшість компаній (як українських, так і іноземних) використовують цю особливість для маніпулювання обсягом прибутку у звітному періоді;

3) бухгалтерський баланс не пристосований для відображення нематеріальних (інтелектуальних) активів, які $€$ основним джерелом конкурентоспроможності бізнесу;

4) фінансові показники характеризують підприємство 3 точки зору фінансового циклу, коли його діяльність розглядається у розрізі руху грошових коштів, а не створення вартості. При такому підході такі важливі напрямки, як взаємовідносини з клієнтами, маркетинг, удосконалення технологій, навчання та розвиток персоналу, розробка нових продуктів і послуг, представлені як суто витратні, що суперечить їхній ролі в сучасних умовах. 
На кожному рівні прийняття будь-якого обгрунтованого управлінського рішення на підприємстві неможливе без детального обліку, економічного контролю та аналізу як фінансового складу підприємства в цілому, так і окремих його складових частин, у тому числі й капіталу, залученого до діяльності підприємства. Це покликано забезпечити необхідною інформацією управлінський персонал підприємства, який відповідає за планування, організацію, контроль та аналіз господарсько-фінансових операцій і приймає в межах своєї компетенції різноманітні адміністративні рішення.

Колишня національна та сучасна міжнародна концепції обліку мають, 3 одного боку, певну схожість (орієнтацію на користувача інформації), а з іншого - значні розбіжності, насамперед пряме використання даних бухгалтерського внутрішньогосподарського (управлінського) обліку безпосередньо для прийняття управлінських рішень менеджерами підприємства.

За окремими оцінками «облік як одна із функцій управління незалежно від форм власності й типу економічних відносин обслуговує управлінський процес, створюючи понад 80 \% інформаційної бази управлінських рішень, що приймаються» [34].

На відміну від фінансового обліку у внутрішньогосподарському (управлінському) обліку вдаються до додаткової документації, наприклад такої, як фінансові звіти, включаючи звіти про рух грошових коштів, та різних фінансових відомостей. Таким чином, даний обліковий метод використовується на практиці для здійснення підприємством функцій планування, контролю, аналізу та прийняття рішень.

Отже, внутрішньогосподарський облік за інформаційним змістом і колом вирішуваних завдань набагато ширший і різноманітніший, ніж фінансовий. Він повністю підпорядкований запитам управлінської структури підприємства. Його дієвість забезпечується орієнтацією на конкретні господарські завдання, вирішення яких грунтується на відповідній інформації про витрати і доходи.

Проте ці два види обліку мають і спільні риси. По-перше, вони грунтуються на даних єдиної інформаційної системи обліку; по-друге, спираються на 
концепцію відповідальності в управлінні господарськими об’єктами; по-третє, їхня інформація використовується для прийняття рішень, хоча й різної спрямованості.

3 викладеного можна констатувати, що бухгалтерський облік як одна 3 найважливіших складових у системі управління повинна бути зважено організованою та чітко регульованою діяльністю науковців та практиків з обліку, поєднувати в собі професійні знання, міжнародний досвід і компетенцію, оскільки від правильності дій бухгалтера залежать ефективне й законне функціонування підприємства. Отже, метою управління $є$ підвищення ефективності господарських процесів. Бухгалтерські дані дозволяють виявляти проблеми управління, а баланс в цьому випадку $є$ звітом, який оцінює ефективність управління. Усвідомлення цих підходів призведе до трансформації бухгалтерського обліку з пасивного нагляду в інструмент активного впливу на господарські процеси. 